\title{
Lähijohtajien muutosvalmius kuntasektorilla
}

\author{
Jenni Kantola, Kirsi Lehto \& Katja Ekman
}

\begin{abstract}
Recent studies have highlighted the importance of managers' role in change. Managers are a lynchpin in the success of a change as they stand closest to employees and they are both implementing change but also being affected by change.

In this study, we explore managers' readiness for change. Readiness for change refers to what employees perceive as the balance between costs and benefits of maintaining a behavior. In practice, it is about psychological willingness to cooperate in bringing the change to fruition.

We interviewed 19 managers in public sector organizations. The findings indicate that strong change readiness of managers requires organizational support, time resources for people management and participative organizational culture. Study highlights the individual experience and interpretation of meaningfulness of change. This can be achieved by communicating the consequences and benefits of change clearly and by engaging managers in change already in the early phase.
\end{abstract}

Keywords: change management, transformative learning, change readiness, public sector

\section{JOHDANTO}

Organisaatiomuutokset ovat koko ajan yhä kompleksisempia (Haveri 2006; Lindell 2017) ja hiljalleen on hyväksytty, että organisaatioiden muutostilanteet eivät ole enää ohimeneviä poikkeustiloja vaan jatkuvasta ja usein kiivaastakin kehittämisestä on tullut nykyisin pysyvää (Mattila 2008, 87). Vaikka jatkuvaa organisaatiomuutosta voidaan pitää elintärkeänä kehittymisen, kasvun ja hengissä säilymisen suhteen (Michel ym. 2013, 761), muutos vaatii aina koko organisaatiolta sopeutumista uusiin toimintamalleihin.
Kuntasektori on ollut muutoksen pyörteissä viime vuodet sote- ja maakuntauudistusten myötä. Vakkalan (2012, 201-203) mukaan kuntaorganisaatioiden johtamisessa on painottunut rationaalinen ja perinteinen johtamisajattelu, kun taas kompleksisissa muutostilanteissa tarvittaisiin enemmän ihmisläheistä henkilöstöjohtamista, jossa korostuvat mm. aito osallisuus, avoimuus, toimiva viestintä ja vuorovaikutus sekä arvostus ja läsnäolo. Muutoksen onnistumisen kannalta on tärkeää, että sitä johdetaan aktiivisesti, avoimesti ja oikeudenmukaisesti (Lammassaari 2014).

Kuntaorganisaation muutosprosesseja tarkasteltaessa on havaittu, että ristiriitoja ja jännitteitä tulee väistämättä prosessin aikana. Muutoksen vastustamisen taustalla ovat usein henkilöstön pelot oman osaamisen riittävyydestä (Lammassaari 2014, 182-188). Organisaatiotasolla muutoksen yhteydessä puhutaan taidosta joustaa ja olla ketterä, mutta kyse on myös koko organisaatiotason toimintatavoista kohdata ennakoimattomuutta ja reagoida yllättäviin tilanteisiin (Gittel ym. 2006; Lengnick-Hall ym. 2011; Viitala 2017). Sillä suunnitellutkaan muutokset eivät aina tapahdu samalla tavalla ohjatusti (Haveri 2006).

Erityisesti lähijohtajan rooli korostuu muutoksessa, jossa vaaditaan uudenlaista osaamista henkilöstön motivoinnissa ja organisaation toimivuuden varmistamisessa (Lehman ym. 2002; Cunningham ym. 2002). Organisaation näkökulmasta johtamisen tulisi pyrkiä tukemaan työntekijöiden itseorganisoitumista ja uusien luovien ratkaisujen etsimistä (Saari 2016, 235-242). Lähijohtajia voikin kutsua niin sanotusti muutosagenteiksi, jotka ovat mukana vaikuttamassa muutoksen suunnitteluun, toteutukseen ja läpivientiin (Appelbaum ym. 1999; Barton \& Ambrosia 2013). Siinä missä lähijohtaja johtaa muutosta, hänen tehtävänään on auttaa työntekijöitään sopeutumaan muutokseen. Lähijohtajan 
työtä leimaa kuitenkin kuntasektorilla kuormittuneisuus, roolien ja vastuualueiden heikko määrittely, paikoin jopa muutosvastaisuus ja ikärakenteen heijastukset muutosasenteisiin (Saari 2016, 235-242). Lähijohtajat eivät ole ainoastaan mukana toteuttamassa organisaatiossa tapahtuvia muutoksia, vaan he ovat myös muutoksen kohteena, jolloin heidän asemansa ja toimenkuvansa saattaa muuttua.

Kysymykseksi nouseekin lähijohtajien henkilökohtainen muutosvalmius (Saari 2016). Muutosvalmius voidaan nähdä voimavarana muutoksesta selviytymiseen. Muutosjohtamisen kirjallisuudessa muutosvalmiutta on tarkasteltu pääosin alaisten muutosvalmius keskiössä, vaikka on todettu, että lähijohtaja, joka luottaa ja uskoo kykyihinsä johtajana, sekä uskoo muutoksen hyödyllisyyteen organisaatiossa, on muutoksen ja epävarmuuden tullessa kyvykkäämpi ja halukkaampi muuttumaan (Vakola 2014). Tässä laadullisessa tutkimuksessa tarkastelemme lähijohtajien muutosvalmiuttakuntaorganisaatioiden kontekstissa. Tavoitteenamme on selvittää, millaisista elementeistä lähijohtajan muutosvalmius rakentuu ja miten muutosvalmiutta voi tukea. Nojaamme tutkimuksessa Armenakiksen ym. (1999) malliin muutosvalmiuden elementeistä (Taulukko 1.).

Armenakis ja kumppanit osoittavat mallilla, mitä pitäisi ottaa huomioon johtamisessa, jotta työyhteisössä saavutettaisiin mahdollisimman hyvä muutosvalmius. Tässä tutkimuksessa käännämme alkuperäisen asetelman ja tarkastelemme sen sijaan itse johtajia ja heidän kokemuk- siaan omasta muutosvalmiudestaan. Käytämme termiä 'lähijohtaja' termin 'esimies' sijaan. Pyrimme sillä edistämään sukupuolineutraalia kielenkäyttöä. Haastattelujen sitaateissa säilytämme haastattelutilanteissa käytetyt termit.

\section{LÄHIJOHTAJA ORGANISAATIOMUUTOKSESSA}

Organisaatioiden muutostilanteita ja niiden johtamista tarkastellaan usein muutosjohtamisen mallien kautta (Lewin 1951; Burnes 2004; Lämsä \& Hautala 2005; Burke 2014). Muutosjohtaminen on laajasti käsitettynä muutostilanteiden hallintaa, jolla pyritään organisaation tehokkuuden ja ihmisten hyvinvoinnin ylläpitämiseen muutoksista huolimatta. Muutoksen on kuvattu etenevän vaiheittain muutoksen valmistautumisesta, uusien toimintatapojen sisäistämiseen ja vakiinnuttamiseen. Muutosjohtamisessa painotetaan yhteisen vision luomista sekä johdon sitouttamista ja henkilöstön valtuuttamista. (Lewin 1951; Kotter 1996.)

Lähijohtajien roolina muutoksessa on sanoittaa johdon muutosviestiä työntekijöille ymmärrettävällä tavalla. Lähijohtajat edustavat alaisilleen organisaation johtoa, ja samalla he vievät työntekijöidensä viestejä johdon tietoisuuteen. Heidän kykyään viedä muutosstrategiaa eteenpäin helpottaa se, että he saavat tarvittavaa tukea omalta lähijohtajaltaan, ja heidät otetaan mukaan päättämään muutoksen toteuttamisesta. Tämä tuki auttaa heitä kohtaamaan omien alaistensa muutospelkoja ja keventämään muutok-

Taulukko 1. Muutosvalmiuden elementit (Armenakis ym. 1999)

\begin{tabular}{|c|c|c|}
\hline Elementti & Määritelmä & $\begin{array}{l}\text { Mihin kysymykseen } \\
\text { haetaan vastausta? }\end{array}$ \\
\hline MINÄPYSTYVYYS & $\begin{array}{l}\text { Yksilön luottamus } \\
\text { muutoksesta selviämiseen }\end{array}$ & Pystymmekö me? \\
\hline JOHDON TUKI & Koettu johdon tuki & $\begin{array}{l}\text { Uskooko johto muutoksen } \\
\text { hyödyllisyyteen? }\end{array}$ \\
\hline RISTIRIITAISUUS & $\begin{array}{l}\text { Ymmärrys muutoksen ja } \\
\text { ideaalin tilan erosta }\end{array}$ & Miksi muutos tapahtuu? \\
\hline SOVELTUVUUS & $\begin{array}{l}\text { Ymmärrys muutostoimenpiteiden } \\
\text { soveltuvuudesta }\end{array}$ & Miksi muutos tapahtuu näin? \\
\hline HENKILÖKOHTAISUUS & $\begin{array}{l}\text { Ymmärrys muutoksesta yksilön } \\
\text { näkökulmasta }\end{array}$ & $\begin{array}{l}\text { Miten tämä muutos } \\
\text { vaikuttaa minuun? }\end{array}$ \\
\hline
\end{tabular}


sista aiheutuvaa vastustusta. (Barton \& Ambrosia 2013, 723-727.) Lähijohtajat voivat kuitenkin kokea rooliristiriitoja johtaessaan muutosta. Rooliristiriidat aiheutuvat siitä, että heidän tulee toteuttaa ylemmältä taholta tulleita muutoslinjauksia ja päätöksiä, joihin he eivät ole välttämättä voineet itse vaikuttaa, ja joiden suhteen heillä ei ole toimintavapauksia. Lähijohtajat ovat siinä tilanteessa, että heidän tulee viestiä, perustella ja auttaa työntekijöitä ymmärtämään muutos huolimatta siitä, pitävätkö he itse sitä oikeutettuna. (McConville 2006, 648.)

Muutostilanteessa johtaminen vaatii lähijohtajalta sensitiivisyyttä, inhimillisten kokemusten ja tunteiden vaihdantaa sekä yhteisen muutostodellisuuden rakentamista (Vakkala 2012, 77). Muutosjohtajan roolia kuvataan usein osallistavan johtajuuden kautta (Laurila 2017; Arola ym. 2020). Laurilan (2017) mukaan osallistavassa muutosjohtajuudessa lähijohtaja kuuntelee alaistensa näkemyksiä ja neuvottelee heidän kanssaan muutokseen liittyvistä asioista. Henkilöstön osallistaminen muutoksen suunnitteluun ja päätöksentekoon lisää motivaatiota, tunnetta työn mielekkyydestä sekä kokemuksia arvostuksesta sekä vähentää muutosvastarintaa. Myös kuntien sosiaalityöntekijöiden näkemyksiä organisaatiokansalaisuudesta tutkineet Arola ym. (2020) pitävät tärkeänä osallistavan johtamisen vahvistamista. He ovat huomanneet organisaatioissa väsymistä jatkuviin muutosprosesseihin. Muutosvastarintaa ovat aiheuttaneet kokemukset ylhäältä alas johdetusta muutoksesta ja siitä, että työyhteisö ei ole voinut vaikuttaa muutosten toteuttamiseen. Henkilöstön muutospelkoihin reagoiminen näyttää olevan edellytyksenä sille, että muutoksen edellyttämään uuden oppimiseen halutaan panostaa. Lähijohtajan rooli muutoksessa nähdään myös valtuuttamisena (Juppo 2011; Vuorinen 2008). Se tarkoittaa johtamisessa tien näyttämistä, rohkaisemista ja yhteiseen visioon innostamista. Esimerkkinä oleminen voi olla muutosmyönteistä asennetta tai sitoutumista muutokseen käytännön toiminnan tasolla. (Salmela ym. 2011; Laurila 2017; Nygaard ym. 2017.)

\section{LÄHIJOHTAJAN MUUTOSVALMIUS}

Muutosvalmiudella tarkoitetaan muutoksen ymmärtämistä ja siihen uskomista (Bernerth
2004, 40), joka näyttäytyy kyvykkyytenä toteuttaa muutosta sekä kokemuksena muutoksen tarpeellisuudesta (Jansen 2000). Valmiuden, engl. readiness, käsitettä on käytetty kirjallisuudessa kolmella eri tavalla. Sillä voidaan viitata yksilön muutosvalmiuteen, yksilön näkemyksiin organisaation muutosvalmiudesta tai suoraan organisaation valmiuteen selviytyä muutoksesta (Vakola 2014). Kirjallisuudessa yksilön näkökulma on vähemmän edustettuna, vaikka yksilön valmius on todettu kriittiseksi menestystekijäksi organisaatiomuutoksessa (George \& Jones 2001, 420). Muutosvalmiutta voidaan kuvata luonteeltaan sosiaaliseksi, sillä organisaation jäsenten muutosvalmius rakentaa muiden jäsenten ja samalla koko organisaation muutosvalmiutta, mitkä samalla vaikuttavat toisiinsa jatkuvasti. (Armenakis ym. 1993.) Siinä missä yksilön muutosvalmiuden ajatellaan rakentuvan yksilön asenteista ja uskomuksista (Armenakis ym. 1993), organisaation muutosvalmius pitää sisällään organisaation rakenteissa olevan kulttuurin, johtajuuden ja viestinnän (Choi \& Ruona 2011).

Siitä huolimatta, että muutosmallit tunnistavat muutoksen keskeisen roolin kiteytyvän henkilöstön muutosvalmiuteen, aihetta on tutkittu melko vähän. Tutkimukset aiheesta keskittyvät yleisesti muutosasenteisiin, joissa muutosvalmius on yksi asenne muiden joukossa. Nykypäivänä muutosjohtaminen voidaankin nähdä oikeastaan ihmisten asenteiden johtamisena muutostilanteessa (Smith 2005, 408). Muutosvalmius yhdistetään usein muutosvastarintaan, jota taas vastaavasti on tutkittu hyvinkin paljon, ja josta löytyy paljon kirjallisuutta (esim. Frahm \& Brown 2007; Krantz 1999; Self \& Schraeder 2009). Muutokseen liittyvien kielteisten tunteiden vähentämiseksi on tunnistettu useita erilaisia strategioita, muun muassa kouluttamisen, riittävän viestinnän, osallistamisen ja neuvottelukulttuurin omaksumisella voidaan vähentää muutosvastarintaa, mutta myös kasvattaa keinoja yksilöiden muutosvalmiuden luomiseksi (Kotter \& Schlesinger 1979). Merkittävin ero näiden käsitteiden välillä on se, että muutosvastarinnasta puhuttaessa yksilöstä puhutaan muutoksen vastaanottajana, kun taas muutosvalmiudessa yksilöllä on aktiivisempi rooli muutoksen kokemisessa (Choi \& Ruona 2011).

Vaikka muutosvalmiutta ei ole tutkittu paljoa, on sen merkitys tunnistettu jo perinteisissä 
muutosjohtamisen teorioissa. Armenakis ym. (1993) kuvasivat, että organisaation muutoksen ensimmäinen vaihe on muutosvalmius, jonka jälkeen voi vasta omaksua ja vakiinnuttaa sekä institutionalisoida sen organisaatioon. Muutosjohtamisen yhteydessä yksilön merkitystä korostetaan muutoksen käynnistymisvaiheen keskeisimpänä tekijänä (Kotter 1996). Henkilöstön tulisi kokea muutos tärkeäksi ja oikeansuuntaiseksi, jotta he voivat sitoutua siihen. Muutosvalmius voidaan yhdistää myös muutoksen lähtötilaan, joka heijastaa organisaation jäsenten asenteita muutokseen. Tämän vaiheen aikana pyritään luomaan muutosta tukeva ilmapiiri, poistamaan epävarmuutta organisaatiossa ja perustelemaan muutoksen hyödyllisyys ja välttämättömyys (Lewin 1951).

Melko uusi kirjallisuudessa esiintyvä muutokseen liittyvä käsite on vastaanottavaisuus muutosta kohtaan (change receptivity) (Frahm \& Brown 2007). Muutoksen vastaanottavaisuuden on todettu olevan soveltuvampi käsite kuin muutosvalmiuden silloin, kun halutaan kuvailla työntekijän asennetta yleisesti muutosta kohtaan ja kun tarkoituksena on arvioida yksilön halua omaksua uusia ideoita tai käytäntöjä, joita muutoksesta seuraa. Muutosvalmius on käsitteenä tarkoituksenmukainen, kun se keskittyy työntekijöiden valmiuteen toteuttaa muutos. (Weiner ym. 2008, 426.)

Aiemmissa tutkimuksissa on todettu, että yksilön valmius muutokseen riippuu siitä, miten hän arvioi muutoksen mukanaan tuomat haitat ja hyödyt. Kaikella tällä on todettu olevan vaikutusta niin yksilön tyytyväisyyteen, muutoksen hyväksymiseen, stressitasoon, mielentilaan ja jopa muutoksen jälkeiseen asenteeseen. (Oreg ym. 2011.) Muutosvalmiuden on todettu lisäksi vähentävän muutosvastaisuutta sekä irtisanoutumisia (Neves 2009).

Muutosvalmiuden tasossa voi tunnistaa vaihteluita, joillakin se voi olla hyvin vahvaa ja joillakin valmiuden taso voi olla hyvin heikko (Oreg ym. 2011). Toisaalta muutosvalmius voi muuttua ajan kanssa kokemusten kasvaessa, sillä muutosvalmius on ennemmin tila, eikä staattinen persoonallisuuspiirre (Choi \& Ruona 2011). Muutosvalmiutta voi myös kuvata tilan tapaan kognitiiviseksi vaiheeksi, joka toimii ikään kuin käyttäytymisen esiasteena. (Armenakis ym. 1999).
Aikaisemmat tutkimukset keskittyvät pääosin siihen, miten henkilöstön muutosvalmiutta voi tukea. On todettu, että yksilön muutosvalmiutta voi tukea rakentamalla organisaatioon luottamuksen kulttuurin ja panostamalla positiiviseen viestintään. Tyytyväiset alaiset arvioivat muutoksesta seuraavan positiivisempia seurauksia ja se taas näkyy heidän asennoitumisessaan muutosta kohtaan. (Vakola 2014.) Choi ja Ruona (2011) puhuvat myös organisaatiokulttuurin merkityksestä, mutta nimittävät merkitykselliseksi tekijäksi oppivaa organisaatiokulttuuria, jossa muutos nähdään mahdollisuutena kehittymiseen ja henkilöstöä tuetaan uudistumiseen. Rafferty ym. (2013) ovat tarkastelleet muutosvalmiutta tiimitasolla ja todenneet, että positiivisella ja luottamuksellisella organisaatiokulttuurilla on suuri merkitys jopa ryhmän kokemaan muutosvalmiuteen. Kulttuurin ja ilmapiiriin avulla voidaan edesauttaa positiivista suhtautumista muutokseen ja vahvistaa kollektiivisesti muutosvalmiutta (Rafferty ym. 2013). Positiivinen käsitys organisaation muutosvalmiudesta vaikuttaa positiivisesti myös lähijohtajan omaan työstä suoriutumiseen, kun taas muutospelko sen sijaan vaikuttaa negatiivisesti työstä suoriutumiseen (Weeks ym. 2004).

Armenakiksen ym. (1999) mukaan muutosvalmiutta voi tukea kiinnittämällä viiteen elementtiin huomiota. Muutosvalmiuden ytimessä on yksilön minäpystyvyys. Käsitteellä viitataan yksilön uskoon omiin kykyihinsä ja pystyvyyteen päämäärien saavuttamiseksi (Bandura 1977). Organisaatiotutkimuksissa pystyvyyden on todettu vaikuttavan suoraan työsuorituksen tasoon ja siten työntekijöiden, joilla on hyvät itsensä johtamisen taidot, koetaan omaavan vahvan suorituskyvyn vaativiin tehtäviin. Yksilöiden minäpystyvyyttä tulisi tukea, sillä se kasvattaa sekä yksilön että ryhmän uskoa selviytymiseen ja muutoksessa pärjäämiseen. Minäpystyvyyden lisäksi muutosvalmius rakentuu johdon tuesta. Henkilöstölle tulee tehdä selväksi, että myös johto on sitoutunut ja kokee muutoksen tärkeäksi ja välttämättömäksi. Keskeistä on myös se, kuinka suuri ero koetaan meneillään olevalla hetkellä ja tavoitteena olevalla tilalla. Ratkaisevaa on, kuinka vakuuttuneita työntekijät ovat muutoksen merkityksestä ja soveltuvuudesta organisaatioonsa. Viimeisenä elementtinä mallissa esitetään muutoksen vaikutukset henkilökohtaisella 
tasolla. On tärkeää, että yksilöille selvennetään mitä muutos tarkoittaa juuri heidän kohdallaan, jotta he motivoituvat muutokseen yksilötasolla.

\section{AINEISTO JA ANALYYSI}

Tutkimus perustuu laajaan KuntaHEJO-tutkimushankkeeseen, jossa tutkimuksen kohteena oli 40 kunnan henkilöstöjohtamisen tila, kehitystarve sekä voimavarat, erityisesti organisaatiomuutoksen näkökulmasta tarkasteltuna. Aineiston keruu toteutettiin v. 2016-2017. Tutkimus oli monitasoinen, ja haastateltavat edustivat organisaation kaikkia tasoja. Haastattelussa käsiteltiin laajasti henkilöstökäytänteiden tilaa ja avoimissa kysymyksissä keskusteltiin organisaatiomuutoksen aiheuttamista seurauksista työhön. Tässä tutkimuksessa keskitymme lähijohtajien näkemyksiin organisaatiomuutoksista sekä analysoimme vastausten perusteella, miten muutosvalmiuden elementit ilmenevät heidän kerronnassaan. Tarkastelussa on 19 lähijohtajan haastattelut kymmenestä eri kunnasta ja kaupungista. (ks. Taulukko 2. liitteessä). Haastateltavat ovat kuntien eri toimialoilta. Heistä seitsemän työskentelee sosiaali- ja terveystoimessa, johon haastatteluajankohtana kohdistui suurimmat muutoshaasteet, mikä myös näkyi haastateltavien vastauksissa. Tosin muidenkin toimialojen johtajat ovat kohdanneet lukuisiakin muutoksia työskennellessään kuntaorganisaatiossa. Kukaan haastateltavista ei sanonut, ettei olisi ollut muutoksen kanssa tekemisissä. Tavoitteena ei ollut tehdä kuntavertailua, vaan ymmärtää haastateltavien näkemyksiä muutosvalmiuteen liittyvistä tekijöistä. Aineisto kerättiin puolistrukturoitujen haastattelujen avulla. Haastattelujen pohjana oli haastattelurunko, jossa oli ennalta määriteltyjä kysymyksiä, jolloin kaikilta haastateltavilta saatiin vastaukset tiettyihin kysymyksiin. Joitakin kysymyksiä täsmennettiin haastattelutilanteessa ja esitettiin lisäkysymyksiä tarpeen mukaan. Organisaation muutosta käsittelevässä teemassa haastateltavilta kysyttiin: "Oletteko jo valmistautuneet tuleviin muutoksiin, kuten maakunta- ja soteuudistuksiin?" "Jos olette, niin miten?" "Jos ette, miten aiotte valmistautua?". Jatkokysymyksiä esitettiin tarpeen mukaan. Ne käsittelivät mm. laajemminkin henkilöstöön vaikuttavia muutoksia edeltäneen kolmen vuoden aikana, niistä selviy- tymistä sekä lähijohtajien saamaa valmennusta ja tukea muutostilanteissa. Haastattelut toteutettiin joko kasvokkain haastateltavan työpaikalla tai puhelinhaastatteluina. Haastattelut olivat kestoltaan keskimäärin yhden tunnin.

Tarkastelemme aineistoa laadullisesti sisällönanalyysiä hyödyntäen. Sisällönanalyysissä aineistoa tarkastellaan eritellen, yhtäläisyyksiä ja eroja etsien ja tiivistäen. Se on tekstianalyysiä, jossa pyritään muodostamaan tutkittavasta ilmiöstä kuvaus, joka kytkee tulokset ilmiön laajempaan kontekstiin (Tuomi \& Sarajärvi 2009). Etenimme teorialähtöisesti, tarkastellen aineistosta muutosvalmiuden elementtejä: minäpystyvyys, johdon tuki, koettu muutoksen ristiriitaisuus ja soveltuvuus ja muutoksen henkilökohtaisuus (Armenakis ym. 1993). Luimme aineistoa muutosvalmiuden kehyksen kautta, analysoiden miten viisi elementtiä tulivat esille haastateltavien vastauksissa ja muutospuheessa. Analyysin luotettavuutta lisätäksemme toteutimme ensin tahoillamme sisällönanalyysin ja sitten yhdistimme keskustellen analyysin. Tämä tutkijatriangulaatioksi kutsuttu menetelmä on työläs, mutta toisaalta se on tuonut esiin erilaisia näkökulmia ja syventänyt analyysiä. (Tuomi \& Sarajärvi 2009.)

Tutkimuseettisistä syistä aineiston yksilötiedot on anonymisoitu ja muutostapahtumat häivytetty, jotta yksilöä ei voida yhdistää tietyn tapahtuman tai tilanteen myötä tiettyyn organisaatioon. Anonymiteetti on myös mahdollistanut haastateltaville luottamuksellisen haastatteluympäristön ja avoimemman mielipiteiden vaihdon, sillä aiheena muutosvalmius saattaa koskettaa hyvinkin henkilökohtaisia kokemuksia, näkemyksiä ja tunteita tai esimerkiksi organisaation toimintatapoja kritisoivaa puhetta.

Tutkimuksen luotettavuutta laajemmin arvioidessa aineiston laatu on huomioitava asia. Tässä käytettävä aineisto on osa isompaa aineistoa, jossa selvitettiin strukturoiduin kysymyksin henkilöstöjohtamisen käytänteitä muutoksessa. Kysymyksenasettelussa muutosvalmius ei ole siis ollut lähtöolettamuksena tai huomioituna, eikä haastateltavilta kysyttäessä ole käytetty muutosvalmiuden käsitettä tai avattu käsitteen määritelmää tai sen rakentumista. Tässä sen sijaan meitä on kiinnostanut se, onko puheessa tullut esille muutosvalmiuden erilaisia elementtejä tai puhetta esimerkiksi omista voimavaroista, us- 
kosta muutoksesta selviytymiseen tai peloista muutosta kohtaan. Nämä kaikki kuvastavat muutosvalmiuden osa-alueita. Haastateltavat ovat kuitenkin käsitelleet omia näkemyksiään, kokemuksiaan, tuntemuksiaan ja tulkintojaan muutoksessa työskentelystä, ja siksi aineistosta on tulkittavissa heidän kerrontaansa muutosvalmiuden elementeistä.

\section{TULOKSET}

Haastattelumateriaalia luettiin ensin viiden muutosvalmiuden elementin kautta. Usean luennan jälkeen havaitsimme, että kaksi elementtiä, ristiriitaisuus ja soveltuvuus, sopivat käsiteltäväksi yhtenä elementtinä. Ristiriitaisuus-elementti hakee vastausta siihen, että miksi muutos tapahtuu ja soveltuvuus-elementti taas siihen, että miksi muutos tapahtuu juuri näin. Nämä molemmat elementit käsittelevät tulkintamme mukaan muutoksen sisältöä ja itse prosessia ja siksi nimitämme näitä kahta elementtiä prosessiymmärrykseksi. Yhteenvetona voidaan todeta, että aineiston haastateltavat kokivat muutoksen olevan monessa tapauksessa vielä hyvin aluillaan tai kesken ja siksi heidän puheessaan ei ollut vielä havaintoja tai ehdotuksia vaihtoehtoisista muutoksen toimenpiteistä ja tämä osaltaan puoltaa sitä, että käsittelemme näitä kahta elementtiä yhtenä. Alla olevassa kuviossa (Kuvio 1.) havainnollistamme aineiston analyysin tuloksia ja erittelemme sen jälkeen tekstissä, miten ja minkälaisin teemoin muutosvalmiuden elementit tulivat ilmi lähijohtajien vastauksissa.

\section{Minäpystyvyys}

Minäpystyvyydellä viitataan siihen, uskooko lähijohtaja saavuttavansa tavoitteensa. Mitä vahvempi pystyvyysusko, sitä enemmän hän on valmis näkemään vaivaa ja ponnisteluja päämäärän saavuttamiseksi. Pystyvyysuskolla on siten vaikutusta sekä yksilön käyttäytymiseen, että suorituksen tasoon (Bandura 1977).

Aineistossa lähijohtajat suhtautuivat muutokseen hyvin eri tavoin. Aineistosta oli tunnistettavissa kolme tasoa: vahvistunut, neutraali ja epäilevä. Muutos saatettiin esittää hyvin neutraalisti ja se nähtiin luonnollisena, jopa arkisena osana organisaatioiden toimintaa ja kehitystä. Tällöin sitä ei koettu myöskään uhkaavana tai liiaksi
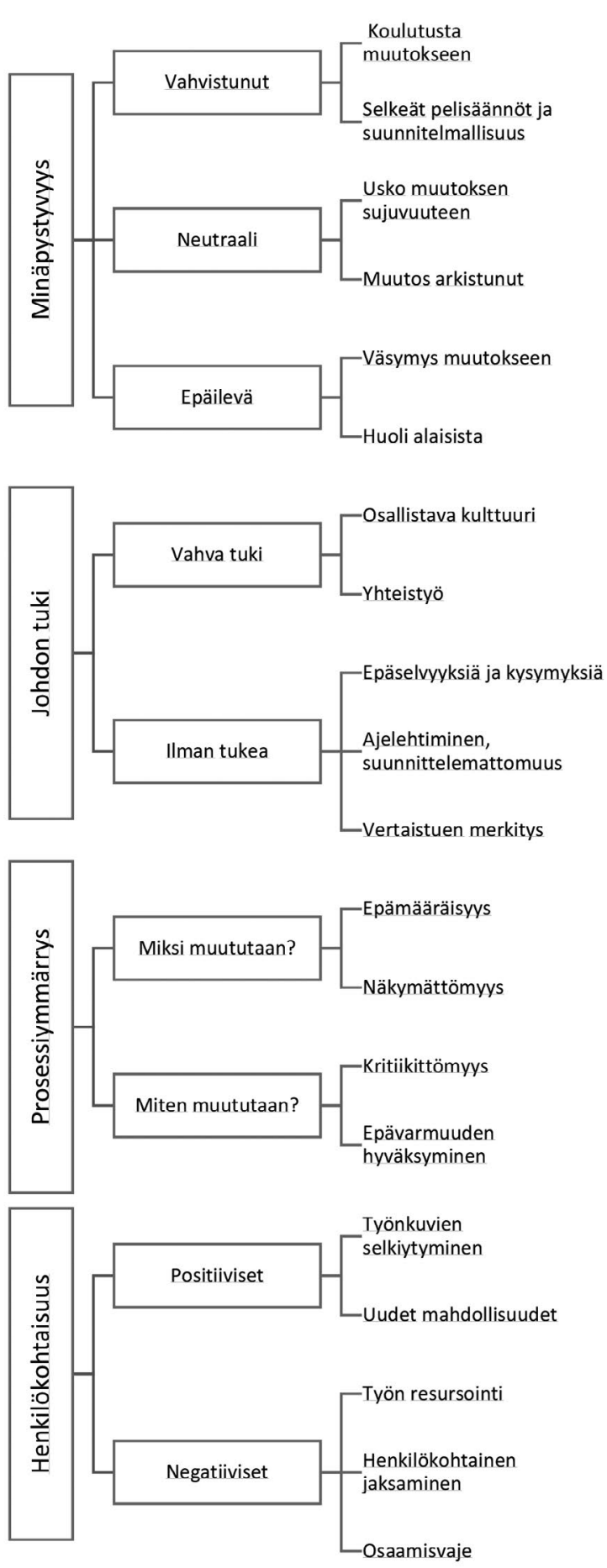

Kuvio 1. Aineiston analyysi 
kuormittavana, vaan se nähtiin ikään kuin asiana, johon voi järjestelmällisesti varautua, ja jonka myötä syntyy uusia mahdollisuuksia. Tämä kertoi haastateltavien uskosta muutoksen sujuvuuteen. Taustalla saattoi olla kokemuksia jo aiemmista muutoksista tai muutokset koettiin tavanomaisina vaiheina toimialalla.

"No muutosta on aina ja se on faktaa, mutta niihin täytyy valmistautua, pitää hyväksyä asiat niin kuin ne on ja oppia lisää. Se luo mahdollisuuksia ja vie eteenpäin.” (Haastateltava 15.)

Vahvistuneissa kertomuksissa katse luotiin tulevaan ja siitä avautuviin mahdollisuuksiin. Luottamusta muutokseen ja siitä selviämiseen lisäsi myös yhdessä tekeminen ja osallistuminen muutoksen toteuttamiseen. Minäpystyvyyttä vahvistavina tekijöinä koettiin muutoksessa saatu koulutus sekä selkeät pelisäännöt ja toteutuksen suunnitelmallisuus.

"Ollaan piirrelty kaavioita ja muita ja käyty yhessä keskustelua eri tasoilla. Sillä tavalla aika luottavaisin mielin" (Haastateltava 2.)

Lähijohtajien kertomuksista välittyi toisaalta myös väsymys ja huoli. Tällöin muutosjohtaminen näyttäytyi perustason työstä selviytymisenä ja muutosjohtaminen nähtiin jonain erityistaitona ja lisäpalana, johon ei ollut aikaa. Epätietoisuus tilanteesta nosti esiin myös uhkakuvia ja lisää epävarmuutta ja epäilyksiä muutoksen merkityksestä ja tarpeellisuudesta.

"Mulla on tällä hetkellä vähän semmonen niinku väsymys ittellä, että nää tämmöset paineet mitä välillä tulee enemmän eri asioitten suhteen. Varmaan sit ku nää asiat muuttuu, niin sitä muutosjohtamista, mutta siihen varmaan koulutusta ja apua saa, että en tiiä. Se on ainakin semmonen kehittämisen paikka." (Haastateltava 8.)

"Mutta toki tässä on nyt nämä uhkakuvat tästä tulevasta, että miten tää nyt sitten, pysyyks se nenä pinnalla vai miten tässä käy et kuitenkin se pelivara on tosi pieni, jos mennään asukasta kohti laskien" (Haastateltava 3.)
Osa koki vahvaa kuormitusta, epätietoisuutta ja painetta tilanteesta, toiset taas hakivat välineitä ja ratkaisuja aktiivisesti muutokseen ja henkilöstönsä tukemiseen. Aineistosta nousi kuitenkin kokonaishuomiona se, että siinä esiintyi vähemmän puhetta lähijohtajan omasta jaksamisesta, vaan enemmänkin huolta henkilöstön jaksamisesta ja heidän tsemppaamisestaan. Lähijohtajat pohtivat esimerkiksi oman asenteen ja sen heijastumisen vaikutusta työntekijöihin ja sitä kautta miettivät, miten heidän tulisi muuttaa käytöstään.

"Luottamus on ainakin yks tärkee mitä lähijohtajalta siinä vaihees vaaditaan. Se että lähijohtaja luottaa siihen muutokseen, ja viestii sitä ympärilleen, niin ne ihmisetkin pystyy luottaan. Mut jos mä en luota, enkä tuo semmosta luottamuksen ilmapiiriä, ihan turha olettaa et noikaan luottaa, et kyllähän se vaatii multa joskus semmost yltiöpositivisuuttakin ja semmost uskon luomista et hei täst tulee ihan hyvä, me selvitään ja pärjätään, vaik itteekin välil saattas pelottaa." (Haastateltava 6.)

\section{Johdon tuki}

Lähijohtajan rooli muutoksessa on kaksijakoinen. Lähijohtajat eivät ole ainoastaan mukana toteuttamassa organisaatiossa tapahtuvia muutoksia, vaan he ovat myös muutoksen kohteena. Siksi lähijohtajatkin tarvitsevat tukea työhönsä ja muutoksen läpiviemiseen. (ks. Barton \& Ambrosia 2013.)

Aineistossa lähijohtajat kokivat helpottavana sen, että jo olemassa oleva kulttuuri tuki muutosta. Lähijohtajien puheissa tuli esiin kokemus joko vahvasta tuesta tai kokonaan ilman tukea jäämisestä. Parhaimmillaan kulttuuri oli osallistavaa, vuorovaikutuksellista ja yhteistyöhön nojaavaa lähijohtajien näkökulmasta. Osallistaminen lisäsi tiedonkulkua ja tunnetta siitä, että muutos oli itselle selkeä.

"Aina kehitettävää on, mutta kyllä silleen peruspelisäännöt on aika selvät. Ja meillä on yleisestikin sellanen keskusteleva ja osallistava kulttuuri, että on aika kaukana semmosesta autoritäärisestä, perinteisestä johtamismallista." (Haastateltava 3.) 
Muutoksessa tukea johdolta saaneet lähijohtajat näkivät sen myös luottamuksen osoituksena. Samalla se lisäsi tunnetta muutoksen hallinnasta organisaatiotasolla.

"Sit tavallaan just et se tuki on kans semmosta et siellä tuen takana on luottamus. Et siinä tulee semmonen olo et okei tohon laivaan kannattaa hypätä." (Haastateltava 6.)

Toinen ääripään kokemus oli, että tukea ei saanut ollenkaan. Tällöin muutoksesta oli paljon epäselvyyksiä ja kysymyksiä ja tukea kaivattiin erityisen paljon.

"Et ehkä semmosta, mitä mä oon kyllä nyt esittänytkin toivetta eteenpäin et semmonen jatkuva pakollinen varaus, että olis varattu sille esimiehen tukemiselle aikaslotteja vaikka kerran kuussa tai jotain. Se on ehkä aika paljon mutta silti, et käytäis läpi niitä asioita et mitä tää nyt oikeesti kellekin tarkottaa vai tarkottaako tää mitään kellekään.” (Haastateltava 16.)

Tukea hakiessa vertaistuki, kollegoiden kanssa käydyt keskustelut auttoivat lähijohtajia muutoksessa. Työnohjaus nousi myös aineistossa esiin yhtenä mahdollisena muutoksen tuen välineenä, mutta vertaistuen merkitys koettiin kuitenkin tärkeämpänä.

"No kyllä mie kuitenkin koen että, mie oon miettiny välillä sitä työnohjausasiaakin mutta mulla on vähän huonoja kokemuksia aikasemmista työnohjauksista niin, koen että ainakin toistaiseksi tämä että saa toisen esimiehen kans keskustella niin, se on aivan, hän ymmärtää mistä puhutaan.” (Haastateltava 8.)

Aineistosta voi havaita sen, että kun lähijohtajat kokivat pääsevänsä mukaan kehittämistyöhön ja päätöksentekoon, silloin oltiin luottavaisempia muutokseen ja tyytyväisempiä tilanteeseen, kuin sitten taas silloin, kun kaivattiin lisää aikaa keskusteluille ja kysymyksille ja tukeuduttiin kollegaan. Tuen toivottiin olevan osa muutosstrategiaa, ja lähijohtajat näkivät, että olisi perusteltua resursoida johdolta aikaa myös lähijohtajien tukemiseen. Kokemus ilman tukea jäämisestä näyttäytyi haastateltavien mielissä muutoksissa ajelehtimisena vailla suurempaa suunnitelmallisuutta.

\section{Prosessiymmärrys}

Muutosvalmiuden yksi kriteereistä on ymmärrys siitä, miksi muutos ylipäätään tapahtuu. Nähdäänkö nykytilanteen ja muutoksen edustaman ideaalitilanteen välillä ristiriitaa? Entä miksi muutos tapahtuu tietyllä tavalla, jolloin on kyse ymmärryksestä muutostoimenpiteiden soveltuvuudesta. Tarkastelemme näitä kahta Armenakisin ym. (1993) muutosvalmiuden komponenttia, ristiriitaisuus ja soveltuvuus, yhdessä, koska aineistossa niihin liittyvät lähijohtajien puheet esiintyivät jossain määrin päällekkäisinä.

Aineiston perusteella voidaan todeta, että Sote-järjestelmään liittyvä uudistus ei edustanut kuntien eri toimialojen lähijohtajille ihannetta, jota tavoitella ja jota kohti mennä (vrt. Armenakis ym. 1993). Muutokseen sitoutumisen kannalta reformin pitäisi pystyä kokemaan tärkeäksi (vrt. Kotter 1996). Strategisuuden puute näyttäytyi aineistossa siinä, että vastaajilla ei ollut riittävää käsitystä siitä, mitä tavoitellaan, miksi muutos tapahtuu, ja miten se tapahtuu. Muutos koettiin epämääräisenä ja osin näkymättömänä sillä tasolla missä lähijohtajat itse sitä arvioivat.

"Se ei näy meillä et se peuhaaminen mitä on, tuolla, tavallaan siellä, sosiaali- ja terveyspuolella niin kyllähän sitä mietityttää ja mikä on sitten se, rajapinta missä me ollaan yhdessä et sitähän me ollaan mietitty ihan käytännön tasolla, että mikä on se. Kun mehän ollaan nyt, selkeesti, tätä, mikä kunta hoitaa." (Haastateltava 4 .)

Valtakunnan tason linjausten ja päätösten puuttuminen ja myöhästyminen vaikuttivat kuntatason lähijohtajien käsityksiin, jolloin kuvaa ideaalista muutoksesta oli hankala muodostaa. Haastateltavien joukossa oli niitä, joilla ei ollut tarpeeksi tietoa tai ymmärrystä muutoksesta, jolloin muutosta ikään kuin odoteltiin passiivisesti.

"Tällä hetkellä tän kysymyksen äärellä, katsomme joko kristallipalloon, joka on kirkas, tai sitten katsomme kuiluun joka on yön synkeän musta" (Haastateltava 13.)

"Oikein kukaan ei tiedä vielä mistään mitään niin se on semmonen mutta, toisaalta me ol- 
laan aika sillä lailla että ootetaan mitä tapahtuu, eihän me muuta voida" (Haastateltava 8.)

"Eihän me oikein niihin osata ite valmistautua ennenkö tiedetään mihinkä meidän pitäisi valmistautua" (Haastateltava 11.)

Kompleksiset muutokset edellyttävät organisaatioilta ja sen toimijoilta ketteryyttä ja joustavaa reagointia (Lengnick-Hall 2011). Edellä kuvatusta epävarmuudesta ja epätietoisuudesta huolimatta jotkut suhtautuivat tulossa olevaan muutokseen realistisesti ja jopa kritiikittömästi. Myönteisimmissä arvioissa muutoksen nähtiin tarjoavan mahdollisuuden kehittymiselle ja eteenpäin menemiselle.

"Ehkä se valmistautuminen on sitä että ku on yleisellä tasolla keskusteltu siitä et jotakin muutoksia on tulossa mutta, ei kukaan meistä vielä, tai jotenki ollaan hyvin semmosella odottavalla kannalla. Mutta päivänselvää varmaan kaikissa palveluissa on että, myös meillä että jotakin muutoksia on tulossa." (Haastateltava 11.)

Lähijohtajien kommenteissa tuli esille se, mitä on tehty tai ollaan tekemässä muutokseen liittyen, mutta toimenpiteiden soveltuvuutta ei erityisemmin arvioitu. Kommenteista kuitenkin ilmeni usko toiminnan järkeistymiseen muutoksen avulla, ja tämän nähtiin tapahtuvan parhaiten askel kerrallaan.

"No sillä tavalla meijän oma organisaatio varmaan nyt tällä hetkellä on käyny jo, lautakunnan ja hallituksen tason että valtuustoon menossa seuraavana että, mikä on sitten se meidän, tänne perusopetuksen ja varhaiskasvatuksen osalta ja vapaa-aikatoimen osalta jäävä, organisaatio sitten ensi syksynä, niin siitä ollaan piirrelty kaavioita ja muita ja käyty yhessä keskustelua eri tasoilla. Sillä tavalla aika luottavaisin mielin ja vähän uuden edelläkin että, tehtävänkuvat avataan ja alotetaan miettimään sitte mut kuitenki et säilyy sitä omaa entistäkin, aluetta mutta mitä tulee sitte uutta ja lisää. Ja sillä tavalla pääsis turhista rönsyistä pois ja sillä tavalla järkeistettäis sitte näitä, tehtävänkuviakin." (Haastateltava 2.)
Samalla tiedostetaan kuntakentän epävarma tilanne ja taloudelliset haasteet:

\begin{abstract}
"Mutta toki tässä on nyt nämä uhkakuvat tästä tulevasta, että miten tää nyt sitten, pysyyks se nenä pinnalla vai miten tässä käy et kuitenkin se pelivara on tosi pieni, jos mennään asukasta kohti laskien" (Haastateltava 3.)
\end{abstract}

Kun oli kyse isosta julkisen sektorin reformista, oli vastaajienkin ehkä hankala hahmottaa kysymystä, miksi muutosta tapahtuu. Muutosprosessia kritisoitiin strategisuuden puutteesta, kuten edellä tuli ilmi. Siihen vaikuttivat mm. muutosten tapahtuminen pitkällä aikavälillä ja muutosten poliittisuus; vaihtuvat hallitukset ja hallitusohjelmat, joiden koettiin aiheuttavan tietynlaista tempoilevuutta muutoksen etenemiseen.

"Joo, kyllä. Mut just tää toinen puoli tästä meiän osaamisesta niin mun mielestä siihen on, tosi paljon saatu tukee ja sillä tavalla mutta että, muutos tietysti kun tää on niin pitkällistä ollu viel jos aattelee nyt Paras-hankkeesta sieltä 2000-luvulta ja aina on kuitenki tullu sitte että no ei nyt oo tai sit tulee hallitus ja taas ei tota ja ei tota." (Haastateltava 5.)

Lähijohtajien rooli muutoksessa ei näyttäytynyt aineistossa passiivisena, vaan heillä oli paljon näkemyksiä muutoksen toteuttamisesta ja vaihtoehtoisista toimintatavoista. Tämä vahvistaa näkemystä siitä, että lähijohtajien rooli voisi olla aktiivisempi muutoksen alkuvaiheissa jo, jotta osaaminen eri tasoilta saataisiin hyödynnettyä parhaalla mahdollisella tavalla.

"Tällä hetkellä tarvittaisiin juurikin niitä hallinnon rajat ylittäviä paikallisia yhteistyömalleja. Ei niin että se on organisaatiossa ylhäältä käsketty ja määrätty et meijän kunnassa, kaupungissa nyt kaikki toimii juuri näin ja näin. Vaan se että eri hallinnon aloja, varsinkin se vähä mitä sinne kuntiin jää, ne linkittyy ja verkostoituu toistensa kanssa, jolloin voitais saada koko hallintoon ja toimintojen synergiaetuja." (Haastateltava 13.) 


\section{Henkilökohtaisuus}

Miten tämä muutos vaikuttaa minuun, on kysymys, jota muutoksen kohtaavat usein pohtivat, olivat he sitten työntekijä- tai lähijohtaja-asemassa. Henkilökohtaisuus näyttäytyy aineistossa positiivisten ja negatiivisten näkökohtien kautta.

Positiivisia näkökohtia tuotiin esille mainitsemalla mm. työnkuvien selkiytyminen ja uudet mahdollisuudet yleensä muutokseen liittyen.

"...vähän uuden edelläkin että, tehtävänkuvat avataan ja alotetaan miettimään sitte mut kuitenki et säilyy sitä omaa entistäkin, aluetta mutta mitä tulee sitte uutta ja lisää" (Haastateltava 2.)

”...meijän pitää jotenkin pysyä mukana tässä maailman kehityksessä. Osa tästä kehityksestä on ja voi olla ihan hyvääkin." (Haastateltava 13.)

Negatiiviset näkökohdat liittyivät työn resursointiin, henkilökohtaiseen jaksamiseen sekä osaamisvajeeseen. Lähijohtajat saattoivat kantaa huolta omasta osaamisestaan ja kyvykkyydestään lähijohtajana. Vastauksista välittyi epävarmuuden tunne ja huoli siitä, onko toiminut lähijohtajana oikein tai tehnyt voitavansa. Tällä on yhteytensä aiemmin käsiteltyyn minäpystyvyyteen. Tällöin lähijohtaja huolehtii omista voimavaroistaan muutoksessa, sekä lisäksi kokee huolenaiheeksi johtamansa tiimin jaksamisen ja pystymisen muutoksen läpiviemiseen.

"Kun tää muutos on kuitenkin tosi vauhdikasta koko aika, ja sitten se että meillä kuitenkin tehdään esimiestyötä pääsääntösesti ikään kuin oman työn ohessa, niin se että olis semmonen varmuus et hei nyt mä oon ottanu huomioon nää kaikki, nyt mä oon nähny nää kaikki pakolliset muutokset tai toimintatapamuutokset tai mul on se varmuus et hei nää ei oo muuttunu, nii et joku semmonen peruspohja joka pysyy stabiilina niin se auttais tosi paljon siin toiminnan suunnittelussa, et sit vois keskittyä miettimään niitä juuri meihin liittyviä muutoksia erikseen." (Haastateltava 16.)

Lähijohtajien kykyä kohdata muutos vaikeuttivat myös puutteet osaamisessa, ohjeistuksessa ja toimintatavoissa. He myös reflektoivat omaa rooliaan ja yleisemminkin pohtivat lähijohtajana olemista ja sitä, onko joutunut rooliin, johon ei ole saanut tarpeeksi tukea.

"...niin mä en usko että kauheen monella esimiehellä ainakaan meillä oo sitä muutosjohtamisen osaamista, ja sit se on semmosta epävarmuutta, niin tavallaan se että kaikki sais sen ohjeen että näin toimitaan, ja vois olla varma että tällä tavalla toimimalla menee oikein et kaikki toimii niin, nii sit myöskin ehkä esimiehet kokis olevansa samassa tavallaan veneessä tai samanlaisen ohjeistuksen ja toimintatavan piirissä, ja vois vähentää sitä epävarmuutta, ja tietenkin myöskin sitä että toimittais samalla tavalla. Se näkyy meillä aika paljon et se on aika henkilöstä kiinni että miten jotain esimiestyötä hoidetaan tai ei hoideta." (Haastateltava 16.)

Haastateltavat toivat esille väsymystään lukuisiin muutoksiin ja niiden myötä lisääntyneeseen työmäärään ja kuormitukseen. Asemansa ja roolinsa puolesta he joutuivat kohtaamaan paljon muutoksiin liittyvää kritiikkiä ja vastustusta. Samalla lähijohtajat olivat luottavaisia siihen, että tukea ja apua kyllä saa tarvittaessa.

"No tällä hetkellä, mulla on nyt tällä hetkellä vähän semmonen niinku väsymys ittellä, että, tähän, ehkä ne on nämä tämmöset paineet mitä välillä tulee enemmän eri asioitten suhteen" (Haastateltava 8.)

"Tai mä oon aina aatellu että muutokseen on mentävä mukaan että, mutta tietenkin se että, ne jotka menee muutoksessa mukaan niin, saa kyllä aika paljon myöskin sit kritiikkiä ja on sitä vastustusta virkamiehissä, varmaan suurta pelkoo että mitä mulle tapahtuu. Mut mä en osaa pelätä semmosta asiaa että, niistä selvitään kyllä ja yhdessä selvitään." (Haastateltava 5.)

\section{JOHTOPÄÄTÖKSET - HAVAINTOJA LÄHIJOHTAJIEN MUUTOSVALMIUDESTA}

Muutoksen johtamista ja onnistumiseen johtavia tekijöitä on tutkittu paljon, ja yhdeksi kriittisimmäksi tekijäksi on tunnistettu inhimillisten tekijöiden huomioiminen (Kotter 1996; Gill 
2003; Vakkala 2012). Tarkastelimme tässä tutkimuksessa lähijohtajien kokemuksia keskellä organisaatiomuutosta muutosvalmiuden käsitteen kautta. Muutosvalmius viittaa yksilön asenteisiin, uskomuksiin ja kokemuksiin ja ennen kaikkea ymmärrykseen muutoksesta. Muutosvalmiutta on tarkasteltu aiemmin pääosin työntekijöiden muutosvalmius keskiössä (Vakola 2014), vaikka organisaation muutosstrategioiden on todettu konkretisoituvan ylimmän johdon sijaan juuri lähijohtajien toiminnan kautta (Laurila 2017).

Muutosvalmius on kuitenkin tila, jota voi kehittää ja tukea vahvemmaksi (Choi \& Ruona 2011; Holt ym. 2007; Vakola 2014). Tarkastelimme tutkimuksessamme 19 lähijohtajan muutosvalmiutta Armenakiksen ym. (1999) muutosvalmiusmalliin nojaten. Tunnistimme, että lähijohtajien muutosvalmius rakentui neljän osaalueen varaan: minäpystyvyydeksi, johdon tueksi, prosessiymmärrykseksi ja henkilökohtaisuuden kokemukseksi. Prosessiymmärryksen osaalue yhdistää alkuperäisessä mallissa olleet ristiriitaisuuden ja soveltuvuuden elementit. Tutkimuksemme mukaan lähijohtajat kokivat tärkeimmiksi heidän muutosvalmiuttaan tukeviksi asioiksi riittävän resursoinnin, muutosjohtamisen tuen ja osallistavan kulttuurin. Muutos näyttäytyi lähijohtajien kokemuksissa huonosti organisoidulta ja hallitsemattomalta, kun muutostoimenpiteisiin ei ollut resursoitu riittävästi aikaa, eikä heillä ollut riittävästi tietoa uudistuksen etenemisestä. Tämä oli omiaan kasvattamaan epävarmuuden tunnetta ja vähensi uskoa muutoksen onnistumisesta. Lähijohtajat kokivat myös, että he kaipasivat tukea työssään erityisesti muutoksen läpiviemiseen, ja jos tukea oli saatavilla vähän, he kokivat roolinsa yksinäiseksi ja vailla määränpäätä olevaksi. Ilman johdon tukea tukeuduttiin vahvasti vertaistukeen, jolla on ilman muuta työssä tärkeä rooli, mutta muutoksessa vertaistuki ei välttämättä ole riittävän informatiivista ja vahvistavaa, vaan saattaa lisätä vain epävarmuutta ja kysymyksiä, jos perusta on olettamuksissa ja huolen jakamisessa. Osallistavan organisaatiokulttuurin, jossa lähijohtajat saivat olla mukana kehitystyössä ja päätöksenteossa, koettiin tukevan parhaiten muutosvalmiutta ja tunnetta muutoksesta selviytymiseen (ks. myös Laurila 2017; Arola ym. 2020).
Muutosvalmiutta tarkasteltaessa tunnistimme, että muutoksen merkityksellisyyden kokeminen luo pohjan muutosvalmiudelle. Muutoksessa yksilö hakee merkityksellisyyttä niin itselleen kuin organisaatiolle, ja jos ymmärrys muutoksen tarpeesta, sen tavoitteista ja keinoista ei ole riittävää, ei muutokseen sitoutuminen tunnu mielekkäältä. Muutoksen onnistumisessa tulisi tiedostaa kuinka merkityksellinen yksilötason kokemus on koko organisaation kannalta (Devos ym. 2007). Tutkimus osoitti, että muutoksen tavoitetilaa oli monen vaikea ymmärtää tai heillä ei ollut tarpeeksi tietoa siitä. Ilman päämäärää muutokseen motivointi ja sitoutuminen kärsivät, ja epävarmuus jättää tilaa monille negatiivisille tunteille hämmennyksestä ahdistuneisuuteen. Ymmärrys muutoksen tarpeellisuudesta ja sen tavoitteista tulisi tehdä organisaation jäsenille riittävän selväksi. Merkityksellisyys linkittyy siten muutoksen visiosta viestimiseen vahvasti (ks. Kotter 1996). Vahvempaa muutosvalmiutta kokivat he, jotka saivat olla mukana päätöksenteossa ja tunsivat pystyvänsä vaikuttamaan heitä koskeviin ratkaisuihin (ks. Barton \& Ambrosia 2013). Merkityksellisyyttä syntyy myös siitä, kun lähijohtaja ymmärtää miten muutos vaikuttaa omaan rooliin ja pystyy hahmottamaan muutoksen tuomat mahdollisuudet. Muutosta suunniteltaessa tulisikin luoda kuvaa henkilöstölle siitä, mitä hyvää muutos tulee tuottamaan ja siten tarjota kiinnekohtia muutoksesta selviytymiseen.

Muutosvalmiuden teoria tarjosi monipuolisen näkökulman yksilön kokemuksiin ja tilanteessa oleviin voimavaroihin. Tutkimuksemme aineisto vahvisti hyvin mallin elementtien olemassaolon, ja ne tulivat esiin kaikkien lähijohtajien kerronnassa. Aiemmissa tutkimuksissa on tunnistettu, että yksilön valmius voi olla heikkoa tai vahvaa (Oreg ym. 2011), mutta tämän laadullisen aineiston varassa emme voineet arvioida valmiuden vahvuutta yksilötasolla. Sen sijaan tarkastelu nosti esiin sen, että lähijohtajien kerronnassa oli verrattain vähän näkökulmia omaan jaksamiseen tai hyvinvointiin. Oman itsensä sijaan huomio kohdistettiin työntekijöihin ja kollektiiviseen hyvinvointiin. Vaikka vasta tuoreempi muutosvalmiuden tutkimuksen kirjallisuus painottaa myös tunteiden merkitystä muutoksessa (esim. Rafferty ym. 2013), tunne- 
puhetta tai tunteiden tiedostamista oli verrattain vähän lähijohtajien kerronnassa ja pääpaino oli negatiivisissa tunteissa, kuten ahdistuksessa ja epävarmuudessa. Muutosvalmiuden tarkastelussa tulisikin pohtia enemmän tunteiden roolia kognitiivisuuden rinnalla. Tunteet luovat pohjaa yksilöiden asenteille ja käsityksille niin itsestään kuin organisaation kyvyistä selvitä muutoksesta, ja siksi tunnepuhe voi myös paljastaa puutteita organisaation toiminnassa tai tuessa muutoksen keskellä.

\section{LÄHTEET}

Appelbaum, S., Everard A. \& Hung L. (1999). Strategic downsizing: Critical success factors. Management Decision, 37(7), 535-552. https://doi.org/10.1108/00251749910285674

Armenakis, A., Harris, S. \& Mossholder, K. (1993). Creating readiness for organizational change. Human Relations, 46(6), 681-704. https://doi.org/10.1177/001872679304600601

Armenakis, A. A., Harris, S. G. \& Feild, H. S. (1999). Making change permanent: A model for institutionalizing change intervention. Research in Organizational Change and Development, 12, 97-128.

https://doi.org/10.1016/S0897-3016(99)12005-6

Arola, M., Pehkonen, A. \& Laulainen, S. (2020). Organisaatiokansalaisuus sosiaalityöntekijöiden ongelmapuheessa. Focus Localis, 48(1), 5-23.

Bandura, A. (1977). Self-efficacy: Toward a unifying theory of behavioral change. Psychological Review, 84(2), 191-215. https://doi.org/10.1037/0033-295X.84.2.191

Barton, L. C. \& Ambrosini, V. (2013). The moderating effect of organizational change cynicism on middle manager strategy commitment. The International Journal of Human Resource Management, 24(4), 721-746. https://doi.org/10.1080/09585192.2012.697481

Bernerth, J. (2004). Expanding our understanding of the change message. Human Resource Development Review, 3(1), 36-52. https://doi.org/10.1177\%2F1534484303261230

Burke, W. (2014). Organization change: Theory and practice. California: SAGE Publications, Inc. 4. painos.

Burnes, B. (2004). Managing change: A strategic approach to organizational development and renewal. Gosport: Pearson Education Limited.

Choi, M. \& Ruona, W. (2011). Individual readiness for organizational change and its implications
Viime vuosien muutosjohtajuuden tutkimus on antanut verrattain paljon painoarvoa lähijohtajien työn tarkasteluun alaisten näkökulmasta ja jatkossa olisi tärkeää lisätä ymmärrystä lähijohtajien roolista ja valmiuksista muutoksessa. Muutosvalmiutta voidaan tutkimusten mukaan kehittää ja tukea vahvemmaksi (Choi \& Ruona 2011; Holt ym. 2007), joten muutosvalmiuden tarkastelu tarjoaa hyvän työvälineen myös henkilöstön kehittämiseen yksilölliset voimavarat huomioiden.

for human resource and organization development. Human Resource Development Review, 10(1), 46-73. https://doi.org/10.1177\%2F1534484310384957

Cunningham, C., Woodward, C., Shannon, H., Maclntosh, J., Lendrum, B., Rosenbloom, D. \& Brown, J. (2002). Readiness for organizational change: A 106 Longitudinal Study of Workplace, psychological and behavioral correlates. Journal of Occupational and Organizational Psychological Society, 75, 377-392.

https://doi.org/10.1348/096317902321119637

Devos, G., Buelens, M., \& Bouckenooghe, D. (2007). Contribution of content, context, and process to understanding openness to organizational change: Two experimental simulation studies. The Journal of Social Psychology, 147(6), 607-630.

https://doi.org/10.3200/SOCP.147.6.607-630

George, J.M. \& Jones, G.R. (2001). Towards a process model of individual change in organizations. Human Relations, 54(4), 419-444. https://doi.org/10.1177/0018726701544002

Gill, R. (2003). Change management - or change leadership? Journal of Change Management, 3(4), 307-318. https://doi.org/10.1080/714023845

Gittel, J., Cameron K., Lim S. \& Rivas V. (2006). Relationships, layoffs and organizational resilience. The Journal of Applied Behavioral Science, 42(3), 300-329. https://doi.org/10.1177\%2F0021886306286466

Frahm, J. \& Brown, K. (2007). First steps: linking change communication to change receptivity. Journal of Organizational Change Management, 20(3), 370-387. http://dx.doi.org/10.1108/09534810710740191

Haveri, A. (2006). Complexity in local government change: Limits to rational reforming. Public Management Review 8(1), 31-46. https://doi.org/10.1080/14719030500518667 
Holt, D.T., Armenakis, A.A., Feild, H.S. \& Harris, S.G. (2007). Readiness for organizational change: The systematic development of a scale. The Journal of Applied Behavioral Science 43, (2), 232-255.

https://psycnet.apa.org/ doi/10.1177/0021886306295295

Jansen, K. J. (2000). The emerging dynamics of change: Resistance, readiness, and momentum. Human Resource Planning, 23(2), 53-55.

Juppo, V. (2011). Muutoksen johtaminen suomalaisessa yliopistouudistuksessa rehtoreiden näkökulmasta. Acta Wasaensia 235. Vaasan yliopisto. Haettu

http://urn.fi/URN:ISBN:978-952-476-335-6:, 30.3.2020.

Kotter, J. P. (1996). Muutos vaatii johtajuutta. Helsinki: Oy Rastor Ab.

Kotter, J. P. \& Schlesinger, L.A. (1979). Choosing strategies for change. Harvard Business Review, 57(2), 106-114.

Krantz, J. (1999). Comment on "challenging 'resistance to change". The Journal of Applied Behavioral Science, 35(1), 42-44.

https://doi.org/10.1177\%2F0021886399351004

Lammassaari, T. (2014). Muutos kuntaorganisaatiossa - tapaustutkimus erään kunnan teknisestä toimialasta. Acta Universitatis Lappeenrantaensis 574. Lappeenranta University of Technology.

Haettu http://urn.fi/

URN:NBN:978-952-265-581-3, 31.3.2020.

Laurila, M. (2017). "Me ollaan kaikki samassa veneessä ja soudetaan yhdessä samaan suuntaan": Esimiesten ja henkilöstön käsityksiä hyvästä muutosjohtajuudesta. Acta Wasaensia 386. Vaasan yliopisto. Haettu https://www.univaasa.fi/ materiaali/pdf/isbn_978-952-476-772-9.pdf, 22.3.2020

Lindell, J. (2017). Muutosjohtajuuden pirullinen puoli. Acta Wasaensia 375. Vaasan yliopisto. Haettu http://urn.fi/URN:ISBN:978-952-476-745-3, 22.3.2020

Lehman, W. E. K., Greener, J. M. \& Simpson, D. D. (2002). Assessing organizational readiness for Change. Journal of Substance Abuse Treatment, 22, 197-209.

https://doi.org/10.1016/S0740-5472(02)00233-7

Lengnick-Hall, C., Beck T. \& Lengnick-Hall M.L. (2011). Developing a capacity for organizational resilience through strategic human resource management. Human Resource Management Review, 21, 243-255.

https://psycnet.apa.org/doi/10.1016/j. hrmr.2010.07.001

Lewin, K. (1951). Field theory in social science:
Selected theoretical papers. New York: Harper \& Brothers Publishers.

Lämsä, A-M. \& Hautala, T. (2005). Organisaatiokäyttäytymisen perusteet. Helsinki: Edita Publishing Oy.

Mattila, P. (2008). Otollinen tilaisuus. Miten tarttua muutokseen. Helsinki: Talentum.

McConville, T. (2006). Divolved responsibilities: Middle managers and roles dissonance. Personnel Review, 35(6), 637-653.

https://doi.org/10.1108/00483480610702700

Michel, A., Todnem, By R., \& Burnes, B. (2013). The limitations of dispositional resistance in relation to organizational change. Management Decision, 51(4), 761-780. https://doi.org/10.1108/00251741311326554

Neves, P. (2009). Readiness for change: Contributions for employee's level of individual change and turnover intentions. Journal of Change Management, 9(2), 215-231. https://doi.org/10.1080/14697010902879178

Nygaard, A., Biong, H., Silkoset, R. \& Kidwell, R.E. (2017). Leading by example: Value-based strategy to instill ethical conduct. Journal of Business Ethics, 145(1), 133-139. https://doi.org/10.1007/s10551-015-2885-9

Oreg, S., Vakola, M. \& Armenakis, A. (2011). Change recipients' reactions to organizational change: A Sixty-year review of quantitative studies. Journal of Applied Behavioral Science, 47(4), 461-524. https://doi.org/10.1177\%2F0021886310396550

Rafferty, A. E., Jimmieson, N. L. \& Armenakis, A.A. (2013). Change readiness: A multilevel review. Journal of Management, 39(1), 110-135. https://doi.org/10.1177\%2F0149206312457417

Saari, T. (2016). Resilienssi työntekijän voimavarana asiantuntijatyön aikapaineiden hallinnassa. Hallinnon Tutkimus, 35(3), 232-243.

Salmela, S., Eriksson, K. \& Fagerström, L. (2011). Leading change: A three-dimensional model of nurse leaders' main tasks and roles during a change process. Journal of Advanced Nursing, 68(2), 423-433. https://doi.org/10.1111/j.13652648.2011.05802.x

Self, D. R. \& Schraeder, M. (2009). Enhancing the success of organizational change: Matching readiness strategies with sources of resistance. Leadership \& Organization Development Journal, 30(2), 167-182. https://doi.org/10.1108/01437730910935765

Smith, I. (2005). Achieving readiness for organisational change. Library Management, 26(6/7), 408-412. https://doi.org/10.1108/01435120510623764 
Tuomi, J. \& Sarajärvi, A. (2009). Laadullinen tutkimus ja sisällönanalyysi (6. uud. laitos.). Helsinki: Tammi.

Vakkala, H. (2012). Henkilöstö kuntauudistuksissa: Psykologinen johtamisorientaatio muutoksen ja henkilöstövoimavarojen johtamisen edellytyksenä. ACTA-väitöskirja. Suomen Kuntaliitto, Helsinki. Haettu sivulta https://www.kuntaliitto.fi/julkaisut/2012/1482-henkilosto-kuntauudistuksissa-psykologinen-johtamisorientaatio-muutoksen-ja, 23.3.2020.

Vakola, M. (2014). What's in there for me? Individual readiness to change and the perceived impact of organizational change. Leadership \& Organization Development Journal, 35, 195-209. https://psycnet.apa.org/doi/10.1108/ LODJ-05-2012-0064

Weeks, W. A., Roberts, J., Chonko, L. B. \& Jones, E. (2004). Organizational readiness for change, individual fear of change, and sales manager performance: An empirical investigation. Journal of Personal Selling \& Sales Management, 24(1), 7-17.

https://doi.org/10.1080/08853134.2004.10749012
Viitala, R. (2017). Henkilöstöjohtaminen tulevaisuuden kunnassa. Teoksessa: Nyholm, I., Haveri, A., Majoinen, K. \& Pekola-Sjöblom, M. (Toim.) Tulevaisuuden kunta. Acta 264. Suomen Kuntaliitto, Tampereen yliopisto \& Valtiovarainministeriö. Haettu sivulta https:// www.kuntaliitto.fi/julkaisut/2017/1812-tulevaisuuden-kunta-acta-nro-264, 8.4.2020.

Weiner, B. J., Amick, H. \& Lee, S-Y.D. (2008). Conceptualization and measurement of organizational readiness for change: A review of the literature in health services research and other fields. Medical Care Research and Review, 65(4), 379-436.

https://doi.org/10.1177/1077558708317802

Vuorinen, R. (2008). Muutosjohtaminen suomalaisessa yliopistosairaalassa osastonhoitajien ja sairaanhoitajien arvioimana. Acta Universitatis Tamperensis 1358. Tampereen yliopisto. Haettu sivulta https://trepo.tuni.fi/bitstream/handle/10024/66405/978-951-44-7485-9.pdf?sequence $=1$ \&isAllowed $=y, 25.3 .2020$.

\section{LIITTEET}

Taulukko 2. Tutkimukseen osallistuneet esimiehet

\begin{tabular}{|c|c|c|c|}
\hline Osallistujat & Rooli & Toimiala & Kuntakoko \\
\hline Esimies 1 & Sosiaalityön johtaja & SOTE & Suuri 50001-100000 asukasta \\
\hline Esimies 2 & Päiväkodin johtaja & SIV & Keskisuuri 10001-20000 asukasta \\
\hline Esimies 3 & Talouspäällikkö & SIV & Keskisuuri 10001-20000 asukasta \\
\hline Esimies 4 & Päiväkodin johtaja & SIV & Suuri yli 100000 \\
\hline Esimies 5 & Sosiaalialan yksikön johtaja & SOTE & Suuri 50001-100000 asukasta \\
\hline Esimies 6 & Palveluesimies & SOTE & Pieni 5000-10000 asukasta \\
\hline Esimies 7 & Kaupungininsinööri & TEKN & Suuri yli 10000 asukasta \\
\hline Esimies 8 & Osastonhoitaja & SOTE & Keskisuuri $20001-50000$ asukasta \\
\hline Esimies 9 & Rehtori & SIV & Suuri yli 10000 asukasta \\
\hline Esimies 10 & Päiväkodin johtaja & SIV & Suuri yli 10000 asukasta \\
\hline Esimies 11 & Sosiaalityöntekijä & SOTE & Suuri yli 10000 asukasta \\
\hline Esimies 12 & Vastaava hammaslääkäri & SOTE & Suuri yli 10000 asukasta \\
\hline Esimies 13 & Rehtori & SIV & Pieni 5000-10000 asukasta \\
\hline Esimies 14 & Koulutuspäällikkö & SIV & Keskisuuri 20001-50000 asukasta \\
\hline Esimies 15 & Sosiaalipalveluiden johtaja & SOTE & Keskisuuri 20001-50000 asukasta \\
\hline Esimies 16 & Palveluesimies & IT & Keskisuuri 10001-20000 asukasta \\
\hline Esimies 17 & Varhaiskasvatusjohtaja & SIV & Suuri 50001-100000 asukasta \\
\hline Esimies 18 & Aluepäällikkö & SIV & Suuri yli 100000 \\
\hline Esimies 19 & Esimies siivous- ja ruokapalvelut & TEKN & Pieni 5000-10000 asukasta \\
\hline
\end{tabular}

